Cornell Law Library Scholarship@Cornell Law: A Digital Repository

Historical Theses and Dissertations Collection

Historical Cornell Law School

1895

\title{
Liability of Municipal Corporations for Negligence
}

Benjamin Levy

Cornell Law School

Follow this and additional works at: http://scholarship.law.cornell.edu/historical_theses

Part of the Corporation and Enterprise Law Commons

\section{Recommended Citation}

Levy, Benjamin, "Liability of Municipal Corporations for Negligence" (1895). Historical Theses and Dissertations Collection. Paper 39.

This Thesis is brought to you for free and open access by the Historical Cornell Law School at Scholarship@Cornell Law: A Digital Repository. It has been accepted for inclusion in Historical Theses and Dissertations Collection by an authorized administrator of Scholarship@Cornell Law: A Digital Repository. For more information, please contact jmp8@cornell.edu. 
LIABILITY OF MUNICIFAI- CORPORATIOIS FOR INEGLIGENCE. $---000---$

THESIS PRESENTED BY

BEHJAMIN LEVY

IFOR THE DEGREE OF BACTREOR OF IAWS.

$-\cdots-0000000-\cdots$

CORNELI LUIVERSITY

SCHOCL OF LAW

1895. 
CONTEWTS.

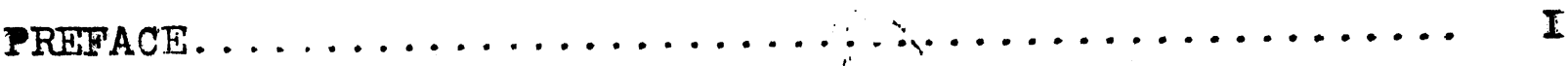

CHAPTER I.

MUNICIPAE CORPORATION DEIIITED.......... I

Section 1. City, Viliage ard Tom............. I

Section 2. Quasi Corporations................... 2

Section 3 . Liability..................... 3

CHAPTER II.

GROLNDS OF IIABIEITY.

Section 1. Theory of Liability..............

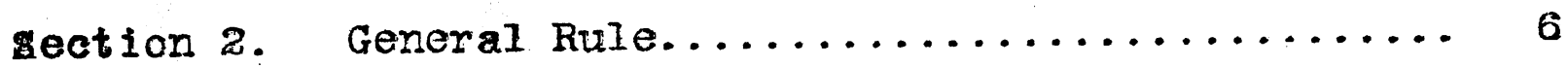

Section 3 . Limiting iiability................ 6

Section 4. Licenses!.................... 8

Section 5. NegIigence..................

CIAPTER III.

MITHS IIOI IIABLE.

Section 1. No General RuIe................ II

Section 2. Public and Frivate Duties............ II

Section 3. Quasi Duties and Liabilities.......... 22

section 4. Quasi offigers..................... Iz

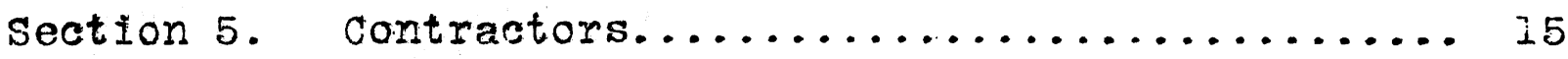


Section $6 . \quad$ icenses....................... 17

CYAJTER IV.

DISCRETIOITATI IOHERS.

Section 1. What is a Discretionary Pomer........... 10

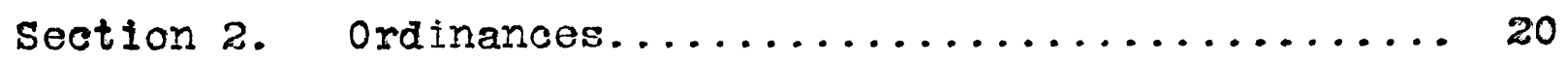

Section 3. PIans and methoi................ 2I

Section 4. UItra Vires $\Lambda$ cts................. 22

Section 5. Liniting itability.............. 24 CHAFTER V.

MINISTERIAL DUTIES.

Section I. Distinguished from Discretionary Duties.... 26

Section 2. As Property Omner............... 26

CHAPTER VI.

STERTIS.

Section I. Liability.................... 28

Section 2. Degree of sere................ 29 CHAPTIR VII.

SLTFACE WATERS.

Section I. Natural Stroans................ 31

Section 2. Surface Drainage................. CHIAPTER VIII.

IIIGHTYYS AND SIDEWALINT. 
Section I. Rules of Liebility.............. 33

section 2. sidemalks.................... 34

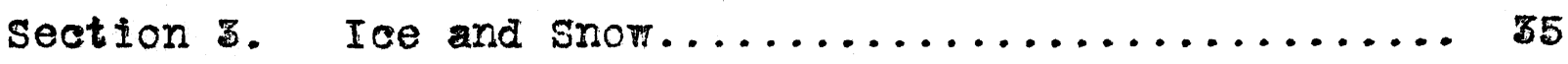


FREFACE.

\section{$---000-\cdots$}

My subject "Wunicipal NegIigence" though a subdivision of the law of mutcical corporations is still too broad to do justice to any phase of it in a groduction of this character. I have only been able to discuss the general principles of negligence; and nerely toldch uron cartain concrete phases which are nost common, but nothing like comprehensiveness has beon attempted.

The sources from which in have obtained ny material is appended. The rorks on PunIic Corporations are linited to Beach, Tiedeman and Dillon. Prom Judge Dillon"s admirable work I have received most aid.

B. I. 
CFLAPTER I.

MUNICIPAI CORPORATION DESINED. $---000---$

All. individuals and corporate liability arises either Irom the common law or by virtue of statutes. (I) In consldering the subject of muicipal Iiability these sources must be kept clear and distinct. "When applied" Judge Dilion, says, "not alone is this distinction established but as practically fapplied ithis tended to promote justine and to secure individual rights".(2) Public corporations are divided into Mnieipal corcorations proper and quasi comporations. A Municipal'corporation is defined by Dilion as "A body politic and corporate constituted by the incorporation of the inhabitants of a city, torn or village for the purpose of local Eovernment." (3) It is corporate chiefly to regulate the internal or local affairs of the city or tom, not for the pirblic but local convenience and in this sense not an agent of the state.(4)

sec. 1. City, JiIiage arci Tomn. Here we mast distinguish between the vernacular and $t$ crretorial or technical meaning of town and village. , Some text writers and courts

(1) Pollock on Torts. page 23.

(2) Dilion on Municipal Corporations 765.

(3) Maratetz on.Corporations 5.

(4) Manilton County $v$ Nighels, 7 Ohio st. IO 
have used these terms in but one sensc, while the term is relative depending uren the territory wherein it is aprlied.(I) In the New England states towns are not territorial divisions, but unincorporated settlenents, - good examples of pure democracy. Their powers and liabilities are linited and for all purposes quasi corporations.(2): In New York town are polttical divisions of the county. In Delaware, laryland, Mew Jersey and other states the term tom is used indiscriminately with viliage.( 3 )

sec. 2. Quasi Comorations. A quasi compration may be defined as a branch of the state, possessing some corcorate faculties and atiributes only granted to aid in performing public duty. (4) Such are the schodI districts, counties, towns in New York, overseers of the foor and the Now England torns.(5) Some quasi corporations are made municipal corporations statute and are. Iiable to the same extent as, the District of Columbia. In New York by the Laws of 1892 all quast corporations are made municipal coryorations for the purpose of suing and being sued. (G) Beartng those distinctions in mind we can fursue our atscussion of munteipal

(1) An \& Eng. Enc. of Lam Vol. 15, 355.

(2) Dilion on Him. Cor. $43-53$.

(3) Enfield v Jordan, IIJ U.S. S30;HiII v Boston, I32 Vass. I22

(4) DiIIon on thun. Cor. 023.

(5) Chap. 687 Lams 1822. N.Y. 
Iiability.

Sec. 3. Liability. Accoraing to the lines of decisions.the quasi corporations(includine the New England toms) are never Iiable to individuals for injuries recelved through Its agents negligence, unless such liability is imposed upon 1t by statute. Theye are political divisions of the state and not subject to Iiability.(I) Thus a county is not liable for neglect to repair public roads, to keep in repair public buildings etc. There is no reason why this distinction should be made between the liability of a city and a county, and an agent of the common council and an agent of Board of supervisors. A county has certain local privileges and advantages as well as cities, In lieu of these privileges given by the state they should be held to strict integrity and diligence as a consideration for such grant, this will in no way interfere with the immunities of state agencies, but such distinction is weIl established in most courts. (2)

In New York actions to recover damages resulting from injuries caused by defects in tho public highway in the counties and towns are of comparatively modern origin. As (1) Dilion on kun. Car. 205.

(2) Cleveland $\mathrm{v}$ King, l33 U.S. 895. 
late as the case of Garlinghouse v Jacobs, 29 N.Y. 227 declded in 13:4, it was hold that the comissioners of the town nor the town itself was responsitle for defects in the highway. But in 1870, the court of Apreals receded from it postition and decided in favor of such actions.(i) The Legislature.in 1881 came to the aid of the courts and by a spectal statute (Laws 1881, Chap. 700) towns were made liable for damages to person and property sustained by defects in the public highway. By the Act of 1890 before roferred to, the town is for QII, purposes of suing and being sued a muicipal corporation. A tom is thus liable eo ingtant f for negiligence of its commissioners, but he is Iiabie to the tom on the judment rendered against the town. This leability is approaching that of the municipal corporation, as Judes O'Brien in 142 N.Y. 515 said, " While in theory the tom is not liable except in cases where the commissioner was or would be liable himself yet it cannot be doubted that tie practical working of the statute has been to enable parties in some cases to recover verdicts against the tom where none rould have been rendered against the comissioner personaliy on the same facts".

(1) Hover v Barkoff, 44 N.Y. 113.

(2) Robinson v Fowler, 30 Supp. 25: Albrecht $v$ Queens county 84 Fin 401: People v Pople, 81 Fim 3as: Dorn v Oyster Bay, 84 Hun 510; Feople v Slater 31 Suxp. 752. 
CIAPBER II.

GROUIDSS OF LIABILITY. $---000---$

Sec. 1. Theory of Liability. A municiral corporation proper is liable for itg negIigonce as a privato corporationThis Iiability does not rest upon statute, but implied from the duty or duties imposed wion it by itg charter. (I) "The "grant of a comporate franchise ta a micipal corporation ", says Judge Coely, "is usually made only at the request of the citizens to be incorporated and it is justIy assumed that 1t confers what is to them a valuable privalege. This privalege is a consideration for the auties which the charter imposes, larger powers are given than are confided to towns or counties, special authority is conferred to make use of the public highways for the special and reculiar convenienco of the citizens of the muricicality in various modes permissible elsewhere." In this respect these corporations are looked upon as occurying the same position as private corporations wich have accepted valuable franchises. Ta bind the city or viliage it must be clothod with sufficient power by its charter to thet end and its resconsibility may (I) DiII on Kun. Cor. 230 
be Iimiled by its creation for its existence is statutory and based upon ax arreement ibotmeen tho sovereign porer of the state and the oorporation by whicin the former confers valuable eranenises and poners and the latter becones bound to certain correspondire ditieg.(1)

Sec. 2. General Rule. Upon the thoory of undertaking duties and assuming tho powers of a private corparation before alluded to, a municipal aororation is liable for its (1) misfeasance, positively injurious to individuals done by muneipal aseits in the course of their emplayment or performance of corporate dutjes,(2) for its mon-feasance or omission to perform as absolute ministerial duty; (3) or for the proper performance of it ecrporate and local duty express or Implied.(2) With the last two liabilities only wiIl we deal.

See. 3. Limiting Iiability. The sources of such liability being the charter and thus statutory it may be limited by charter or statute and it would also follow that its liability may be enIarged. Thts is the case in many eities of New York state. Some eities exempt themselves from lia-

(1) Cain $v$ syracuse, 20 Fin 605 .

Heet $v$ Broekport, 16 N. Y. $16 I$.

(2) Morril on City lieg.6I

Thompon on Negligence 732. 
blitty as Brooklyn for its xegligence, but the rody if any, Is only arailable against the offieers individually. Although this aet was held constitutional the latier cases held, "Unless the duty has been plainly devolvod upo some officess of the eity acainst whom a remedy an be had the remedy must be agaix ot the eity"(1) Binghamtor's eharter is the same as Brooklyn's charter on this point and the lattor eases are followed, also the charter of.ogdensbure. The enarter can derine the negligence and Iinit the negligence of muicipal corparations, it ean require preseatment of elaims before suit and within a time Iinited.(z) A eity eanot relieve itself from liability for its negligenee in the eare of streets by imposiag the same duty upox the orners of the adjaent lots. The abutting omers are not primarily answerable for care of the highways.(z)

A charter provision requiriag lot dmers to keep their sideralks in repair does not raise the presumption that the lot omners have done thoir duty so as to free the eity.(4) Serviee of notiee by the eity to make repairs does not relieve for resulting injuries. But in all eases of sueh

(I) Fitzpatriek v sloeum, 89 N.Y. 853. Fitzeerald v Binghamton, 40 liun 32.

(2) Van Vrake v Sehenectady, sI Hux 516. Gray $\checkmark$ Btooklya, 50 Bari. \$65.

(8) Miven $v$ Rochester, 76 H.Y. 619. 
liability the ultimeth liability is won bite author or the maintainer of the nuisance and a suit lies acainst him. If defendant fail to keep his hatch door in proper repair and safe condition he is liable to a person injured, and it being the duty of the eidy to keep its streets and sideralks in repair it could also be held liable. The parties are analogous to joint tort feasors and an action Iies against : either or both.(3)

A elty chater may require all Iegal remedies to be brought against the owner of the Iand eausing the derect in the eirst instant, (but sueh act is strictly construed.(1) A eity is not held to the nithest degree of eare, of insuring the safety of the streets, so it way happen that while a sutt does not Iie against the eity for its breach of duty, It may against the individual, and a suit unsatisfied against one is not a bar to a suit against the other.(2) The munieipality and the yroverty owner are not in pari delicto or joint tort leasors to bar indemnity or an ation over. (4) See. 42 Licerses. In ease.the obstruction was caused under a Iicense, the right of recovery over depends upon the (1) Raymond $v$ Sheboygen, 70 wis. 313.

(2) Severn $v$ Eddy, 52 III. 189.

(3) Livingstone $v$ Bishor, $I$ Jominon $R .290$. Chitty PIeading 36-8\%.

(4) Lowell v Boston R.R. 23 Fick. 24. 
lieensee's contraet, express or imrlied, to jerform the aet permitteo in such a manner as to protect the public from danger and and the efty from an aetion acainst it.(1) But a wrongdoer causine an tunsafe street without contract or lieense is liable to reeover over upon the principle that he is a guarantor of the safety of the street. Notice of suit brought and opportunity to defond, to the person earsing the injury by the corporation intendine to hold him. If the ormer had express notice of stien peydency and could have.defended, he has been held to be coneluded as to the existenee of the defeet as to the eopporation and as to the damages it oceastones.(2). But the courts hold sueh judgment after notice only prima facie evidenee of the validity of the elaim thereby established.(3) The omission to give notice does not go to the right of the astion, but simply changes the burden of proof.(4)

See. 5. Hegligence. A munieipal corporation is not an insurer against every accident upon its streets, nor is every defeet actionabie. But here as in personal liability the munioipality must be under a duty and for the negligent

(1) Port Jervis v Bahk, 96 N.Y. 550.

(2) Troy v R.R. 47 H.Y. 475.

(3) Bridgeport V Wilson, 34 N.Y, 375.

(4) Aberdeen $v$ Black, 6 Hill 324. 
exereiso of that duty it is liable (I) and whether that is done or not is a praetical question of fact to be determined on trial in each casc.. So also it is essential to liability that the plaintiff should have used reasonable or ordinary care to avoid the accident as neglicence on his part rould prevent recovery.

Reasonaile eare is always the test, and whether tho streets or publie property was in safe condition is a question for the jury.(2) In construeting sewers, drains, grading roads etc., a municipal corporation is bound to ex-, ereise that care and prudence, which a diserete and cautious person would use if the Ioss or rist were his own. $(3)$ The degree of care and foresight which it is necessary to use must alvays be in proportion to the nature and magnitude of the injury that will be Iikely to result, the care in a eity being reater than that required in a viliage.

(I) Dilion, 980.

(2) Huston V N.Y. 9 N.Y. 163. Evans v Utica, 60 M.Y. 166. Todd v Troy, GI N.Y. 506.

(3) Rochester Co. V Rochester, 3 N.Y. 463. 
CHLAPTER III.

WIIN WOT LIABLE

$---000---$

Sec. I. No General Rmle. Where the duty is imposed by statute, the liability rust be within the purpose and intent of the statute.(I) But in the aisonee of statutory liability as we have seen, the munieipal eotporation is liable only in eertain adjudicated eireumstances. What these are is defieult: to detemine, Kr. Justice Foote has said, "all that ean be done with safety is, determine each case as it atises: (2) We will first consider when a municipal corporation is not liable for its negligonee.

See. 2. Publie and Private'Duties. A municipal corporation is not liable for omission or commission of any aet acuring while in the perfomane of a politieal duty, laid by the state for the public benerit as distinet from loeal or corporate advantages.(3) The power here is intrusted to it as one of the poIitical divisions of the state and is conferred, not for the immediate benefit of the munieipality, but as a means to the exercise of the sovereign power

(I) Loyd V W.Y. 5 H.Y. 362.

RadeI iffev Mayor, 4 N.Y. 195.

(3) Dilion, 906. Hill v Boston, 122 Mass. 344.

(3) Loyd V W.Y. supra. 
for the benefit of all its citizens, the corporation is not Itable for non-user nor for misuser by the public acents.(I) "The corporation of the elty of Now York possesses two kinds of power, one of governmental and priblic and to, the extent they are hold and exercised is clothed with govereignty: the other, private and to.tho extent they are held and exercised is a lebal individual. In the former the corporation cannot be held, in the Iatter the auty is clearly ministerial and falls under private powers."(2) But where the liability is Iixed by statute the rule cannot apoly, a statute may give an action against the state or any of its administrative agencies. In the Now England towns no such distinction is necessary, all departments of state being public and for the comon banefit, no action lies, in absence of statute.asainst them.(3)

sec. 3. Quast Dutied and Liabilities. It is in this connection that the courts distinguish betroon quasi and munIcipal corporations.. Quasi corporations, mere political divisions of the state havine forers and duties common to the public are not liable to individuals in the absence of statute, for the breach of such duties.(4) When the municipal cor-

(I) RadcIiff $v$ Hayor, 4 H.Y. 195.

(2) Maximillan v Hayor, 52 N.Y. I64.

(3) Mower $v$ jeicester, 9 Lass.347.

(4) Enoy of Lair Vol. 14. page 1143. Lorillard $v$ honroe, II K.Y. 392. 
poration exercises such functions as a political duty to the public, or through officers appointed by the state, they are not liable for such neglizence in perforning thoir obligations. "There is a iversity of opinion"says J. Dilion, "as to when duties are corporate and when the officers, though appointed by the corporation are to be regarded as the officers of the muicipality and not of the state or public cenerally"(I)

Sec. 4. Quasi offigers. Not every officer of a municipal corporation, thougin appointed and removed by it, is its acent within respondeat superion, nor officers elected directly by the people or appointed by the legislature, even if the city is obliged to pay their salaries.(2) If the officer or his subordinate is appointed to perform a public duty, and not one undertaken by the municipality, whether appointed by the state or city, then he is a public or quasi and not a municipal officer. Such officor cannot be regarded as an arent of the city for whose negligence or want of skiII it can be held Iiabie.(3)

In order to clothe an officer as a minicipal servant, he must be engaged in a local, private duty, apjointed by and (I) Dilian, 96\%.

(3) Shearman and Reafield on Nesitence, 205.

(3) BalIy $\vee$ H.Y. 3 IIIII 53 I.

Fisher v Boston, I04 Mass. 87. 
paid by the municipality in such capacity and have control and power to remove him. It is only in these caperities that the city is Iiable for negligence of its agents and their acts. Only when it is within their scope of official duties and as before stated, a private and not ap public function. The rule respondeat superior mut be applied within the bounds of municipal as distinguished Irom quasi corporate function.

Police officers and police departments of a city are not Its agents, so as to rendar the corporation responsible for neelect de duties to individuals, unless expressly provided by statute.(I) Neither is a oity liable for neglicence of Its Iiremen and fire department appointed and pald by it: their duties are for the public and not for the corporate Interests.( $z)$ The same principlo apties to city boards, of public charity; of hospitals; of health; of poor.(3) or any distinct clty board provided by state legislature as, Board of Revision,(assessment) water connissioners, department of public instruction or public morks in the city of men

(I) Meritto v Baltinore, a Ma. I60:'Phila. $v$ Galverston, 71 Pa. St. 140: IKanz v Trot, 36 Hun 615.

(2) OMora v layor, I Daly 425; Smith v Rochester, 86 N.Y.513; Dilion, 976.

(3) Naximilian v hayor, 62 H.Y. 160; Conrad v Ithaca, 16 H.X. 150 


\section{York.(1)}

But the city is Iiable for the neglicence of engineers, boards of health, park.comissioners, executive boards, water boards etc., when it has the arpointment and surervision, and when the duty is for the local or direct benefit of the corporation and not uItra vires.(2) This Iiability is based upon the right which the employer has to elect his servants, to direct and control them, and to discharge them if not competent.(5)

sec. 5. Contractors. The principle of respondeat superfor as a rule extend to cases of independent contractors, Where the principal has no controI in.the manner and method of performing the contract. But this rule is modified in Its application to muicipal contracts. A municipal corporation cannot in any guise throw off its imposed duties by contracting work on its streots, and this is true although the contractor is independent, for all other purposes. It is immaterial as respects prinary liability whether it has or has not inserted such a disavowal of liability in its contract.(4)

(1) RusseI v New York, 2 Denio 46I; Ehrogot v N.Y. 96 N.Y.264

(2) Marril, 95.: Toony V K.Y. 12 Hun 297.

(3) Kelly V N.Y. 11 H.Y. 432.

(4) Stowrs v Utive I7 N.Y. 104: 'Harrington $v$ Lansingurgh, II0 N.Y. I45; Brusso V Bufialo, $40 \mathrm{N.Y}$. 679. 
The New York cases beeInnine with Blake v Forris, 5 W.. 48 decided in 1807, follored by Fack v Mayor 8 N.Y.52a that where the city officers anerinteid the work, it does not necessarily nake the city liable if the contractor is otherwise independent. In storrs $v$ Utica, I7 H.Y. IO4, folloured in many courts, the doctrine is, that where the accident was the result of the work itself in the actual porformance of the very work contractud for the corporation still remains Iiable. As stated by J. Dilion "respondeat superior does apply where the contract directiy requires the jerformance of a work intrinsically dangerous however skilfuliy performed." In such a case the party authorizing the wark (city) is justIy regarded as the althor of the nischiof. resulting from it whether he does the rork nimself or lets it out by contract.

Where the obstruction or defect is purely collateral to the work contracted to be done and is entirely the wrongful act of the contractor or his morksien, the rule is that the aity is not liable." But where the injury results directly Prom the acts which the contractor agrees and is autrorized to do the city is equaliy Iiable.(I) Thore tho work is of itself a nuisance or is zecessarily dangerous the comoration is bound not only to require the contractor to take every (1) Robins v Chicaco 4 Jall. 679.: Jic Caffrty $v$ The Laften Co. 61 N.Y.I73 
reasonable and Froyer Erocaution to grevent any mischief ensuing, but to soe that such rrecautions are taken by the contractor. Ixcavations contracted to be Inished,- 'tt. Was held that the city was Iiable for injury to the glaintifi because the excavations were needlossly and neclicently suffored to be in the street for an urreasonable leneth of time, and for that, responsitility attached to the city.(1)

seo. 6. Liconsoos. consent of a runicisaltfin pursuance of its authority to a citizen to excavate or obstruct a public street does not rake it respansible for the wrongrul or negligent manner in which the licenseo and his employees do the rork. (2) The licensee is amerable to individwals who may have suffered fron their negligence or by reason of misuser of the Iicense.(3) If the grant of license in excess of the cortorate and injury resulted from it the corporation $\mathbf{1 1}$ I not be protected,(4) but not where the grant is In good fatth and a vere misconstrugtion of its powerg. The Iicensees of a micival comoration remitted to exercise any indepentent wade or busiress for their om profit are not the agents of the corporation, so as to rake it impliedly

(1) Shearman ic Redicield, 393.

(2) Fogel v H. Y. 82 M.Y. 10.

(3) Port Jervis v Bant, ge M.Y. 55: Ghearmen c. Fenficld, 263.

(4) People v Brooklyn, 35 H.Y. 349:Earton v Syracuse, 36 M.Y.54. 
Itable on the principle of respondeat superior.(I)

These rules are subject to the general liability of the city, to Foer its strouts in safo and uropor condition and the corroration is the hold for injuries calused by odstructlons or excavations greatod oy thoix Iiconses. In alI grants of privilege to intertere with the duty orad to the walic, It is neverless bound to exerciso a smoprision of tile work so as to grovent consequent injuries, $(2)$ or a private individtal to lay pipes from the iain to their houses the city mast provide all means to prevent consequential injuries. Speaking Eeneraliy a city is not liable for the acts of persons acting with Iicense, except after due notice to charee the city, under goneral liability to keep streets in safe condition for travel. (3)

(I) Dillon, 955.

(3) Shearman \& Redicla, 353: Storrs v Utica, I7 I.Y. I04.

(3) Fuston v N. Y. 5 Sandford 304; CambelI v Stillvater, 31 Alb. Lav Journal 1I0; Grifin v N.Y. O T.Y. 450. 
CHIAPTER IV.

DISCRETIOWARY FOWERS. $---\theta 00---$

sec. 1. What is a Discretionary Porrer. A nunicipal corporation is not impiedly Iiable in an action for damages etther for the non-exercise of, the rotive or marrer in which, In good faith it exercises its leglslative or judicial power.(1) In the negligent or non-exerctse of such discretion they.are not Iiable.(B) It is not liable for its failure to provide for the removal of a nuisance, ( 8 ) or to exercise its power to supply water and aptaratus for extinguishing fires,(4) or for Injuries to supply suitable drains and sewers or any drain or sewer at all.

Where the duty, alleged to have been violated is purely a judicial one, no action lies in any case for misconduct, houever gross in the veriormance of then. Althongin the officer acts corruptly and ansmerable criminally, he nay not oe liable civilly! A eity has pover to oren streets and for doine so, is not liable even if it aiscommades a morerty owner-(5) The need of drains, sewers, culverts, walis, paving, grading (I) DiIIon, 94a: Rachesior do. V Rochesior 52 J. Y. 4ij.

(2) Cain v Syracuse, 95 N.Y. 01. Dilion, $357,377$.

(3) Carr $v$ Worthorn ilverties, $78 \mathrm{Ar}$. Doc. 344.

(4) Smtth V Rochester, 70 N.Y. 503. 
etc. Is a discretionary power of the legislature of the city and no action can be sistained, for the ruaner of plan or (time) time of continuing it.(I)

But Iudge Taylor says (2) "these duties so ringle as not to be easily distinguishod from each other. Ministerial duties must not be violated with inpunity altrough imposed upon a judicial officer. Thus a power may be given to build sewers whether they shall be constructed, and what places, and to what extent, is discretionary with local Iegislation, While the dity if the work is undertaken, of proper care and afterwards, of necessary repair becomes an absolute duty. "( 3 ) Sec. 2. Ordinarces. Fallure to enforce ordinances or by-laws without notice--- A city is not impliedly bound to secure a perfect execution and regulation of its by-laws and It is not such negIigence as to render the eity Iiable for the manner in which, the ordinances are executed, any more than the state rould be liablo for any imperfection in carrying out its administrative duties. An injury resulting from the want of regulations or ordinances: or from an unreasonable or iegligent apolication of existing remedies, can have no re(1) MilIs $\vee$ BrookIyn, 32 M.Y. 495 .

(2) Cain $\vee$ Syracuse, פ5 N.Y. 9I.

(3) WtIson $v$ kiayor, I Denio 325: xills $v$ BrookIyn, supra. 
aress from the city. "The contrary doctrine" says Judge Denio, "world obligo its treasurer to make good to every aitizen any loss which they might sustain for want of adequate 1atrs. "(I)

This it was held that fallure to yass or execute certain police ordinances; to prohibit swine from runnine at large; or to establish stroct Erades; to maintain a requirea number of men in certain departments;or to take required bonds from auctioneers, Will not render the corporation amenable to an action.(2) Though not actionable, these cases may bind the corporation by continuous disregard of the needs of the city and after notico.( 3 )

Sec. 3. PIans and Lethod. Por a mistake, defect or error in the plans of constructing or repairine drains, severs, roads etc. the corporation is not responsible.(4) But the exercise of a judicial or a discretionary porer by a municipal corporation which results in a direct anci physical injury to the property of an individial, and which irom its nature is liable to be repeated and cortinued, and is remedial by prudential measures renders the corporation liable for such (1) Levy v H.Y. I Sarde. 465. Forcyth v Allanta, I2 Am. R.576. (2) Thourson on regIigence, 732 note 2 jiun $V$ K.Y. 47 N.Y. 639. (8) MC Gintyrv N.Y. 5 DuOr 5.57.

(4) Johnson v D: of C. II8 V.S. 2i:Hiller v Brooklyn, 32 N.Y.489 
damares as occur in consequence of such continnance of the ortginal cause after notice and an omission to adopt such remedial measures as experience shom to be mecessary and proper.(1)

This distinction is firmly established in the Nev York courts.(2) Thompson says, "The distinction is repugnant to justice and destitute of solid foundation in reason.(3) This rale would guard public infringenents of private property." It pactically prohibits taking private proporty for public use. As private corporations, cannot morix an injury to the citizens without compensation any móre than individuals, so public corporations cannot. (4)

Sec. 4. UItra Vires Acts. A corporation is not liable for acts of persons, color officio, acting beyond their authority. So where an injury results from an act wholly beyond the gowers conferred upon a municifal corporation; the latter camnot be neld restonsible in darnages for the doing of 1t. We habe freviously stated that a city is only liable for imosed, express or necessarily implied duties, and not those which are uItra vires.(5)

(I) Wood's I aw of Nuisance, 752.Siefert v Brooliyn, IOI N.Y.I42 (2) Iynch $v$ Hayor, $76 \mathrm{H} . Y$. 60:Watson $v$ hingston, 43 Hun 367. (3) Lansing $v$ Farlan, 87 jich. 15\%:

(4) Nevins $v$ Peoria, $4 I$ III. 502.

(5) Thompson on fegligence 737; DiIion, 958-359. Cuyler $v$ Rochester, I2 wendelI 165. 
Suck want of power must be presinod to be known to all oncerned, for this is the purgose of liniting the charter powers.(I) The acts of the agents may be ultra vires and roid and no Iiability attachos to the princival.(2) The corvoration is not estopied to set up the nullity of its agent's proceedings, the officer himsel way remain liable.(3) The Eeneral rule is unquestionably settled but the aglication 1s best met by the circunstances in each case. Some courts are seemingly in conflict but they may be reconciled by the differences in their charters and the extent of their implied powers.(4)

But an exception exists in pleading ultra vires in keepIng the strests in safe condition. It originated withe Mew York Court of AppeaI and is followed in many otmer courts, To aply the utra vires defense to keeping streots in safe condtion would make all sorts of nuisances tolerable.(5) This superior duty to its streets, checks the passible immunity from ali legal abstructions.(6)

(I) Sonumacher $v$ st Louis, 3 jo. App. 299; Pekin $v$ Nevell, 26 III. 330

(3)Boon $\mathbf{v}$ Uttce a Barb. I03.

(3) Hoag $v$ Vanderberg, 6 Ind. 51I; Smith $v$ Rochester,76 H.Y.500 (4) Stanley $v$ Davenport, 54 Iora 463.

(5) Mayor $v$ Cunliff, $2 \mathrm{~N} . \mathrm{Y}$. . 165; Cohen v layor, IIJ N.Y. 532.

(6) Boom v Utica, surra. 
Sec. 5. Iimiting Liability. As the city derives its existence and power by virtue of its charter, can the clty IImit it I lability for negIigence thorein? As to the former there can be no question, but can the city contract aray all its liability? The corporation can place any reasonable restriction woon its citizens as a condition precedent to an action, as to bring action within certain time, ; Hotice to be filed, or other formality, way be imposed. But these are strictly construed and may not aply to actions ex delicto.

A serious question arose under the Brooklyn charter which read, "The city of BrookIyn shall not be liable in damages for any misfeasance or nonfeasance of the officers... .....but the remedy shall be againgt the officers rersonally if at alI."(I) J. Barnard in Gray $v$ Brooklyn ( 2 ) in deciding that this charter provision was constitutional, said "The city exists only by force of the law creatine it, this Iav is stibject by the constitition to alteration and repeal. I am Ginable to see why tho same legislature may not create a city and Iinit its liability." But a remedy must be available agatnst the city and if not against its officers. The grimary duty to keep its streets in revair, rests upob the city and unless that duty is glainly devolved uxon sone officer or (I) Harrigan v BrookIyn, IIO N.Y. 153.Hunt v Oswego, 107 K.Y. 629. Lavs of 1373, Ch. 27.

(2) 50 Barb. 365 . 
officers of the city, againgt whom an action can be had, the remedy is against the city.(1) This and subsequent cases Iimit any shifting liability to such cases, where tinc duty is clearly throm upon some officer or afficers, But where the absolute duty rests soldy iron tho corworation, it can be frimarily held under the strongest Iinitations, (2) a contrary conclusion would sive inmicipal corgorations a great stretcie of power.

(1) Iitzpatrick v SIocum, 89 H.Y. 305.;

(2) Mardy $v$ Brooklyn, 90 I.Y. 255. Vincent $\checkmark$ Brooklyn, 31 hin 12a, 516. 
CHAPTER V.

MIMISTERIAL DUTIES.

Sec. I. Distinguished from Discretienary Duties.

The

imposed duties wether express or implied, when cerfect duties, as distinguished froin discretionary duties must be carried out wit due care and diligence, and for negligence in such performabce is Iiable to the injured indiridual.(1) The ministerial duties of municipal corporations are various. The classes raich Eive rise to most litigation grow out of the exercise of the judictal and discretionary powers in a negligent manner, makigg public ingrovement, repairs etc.(2) in the improper management and control of its proverty they must not invade private property rights; and in the control of streets, bridges, malks, sewers etc.

Sec. 2. As proverty anner. A municital corparation is in its private cafacity, as the owner or lessee of lands, chattels etc. to be regarded in the sarie Iight and liable to the same extent for its negIigence as individuals are.(3) It is not necessary to allege title in the city, for although it has legal titie but not ordinary control and enjoyment as

(1) Thomson on Negligence, 73I;Disbror v Fingstom,102 N.Y.210 Jenny V N.Y. 120 i.Y. 264.

(2) Thompon on NegIigence, 733.

(ङ) Dilion, 985. 
omers it. ViII not be responsible.(1) Public highways are not to be considered private property of the city strictiy, although diligent use and management is required;(2) semers, water pipes, gas pipes and plant may be owned as private property by the city.(5)

A corsoration oming and receiving revenue for a fublic butlding or rate of it, although not liable for its use in a public capacity, is liable the same as a rrivate landlord for an injury to one, by reason of its neglect to keep a competent janttor.(4) A farm suparvised by a city, a market or water lant owned by a city are all subject to the same prinaiple.(5) A city cannot maintain immigration sheds causing contageous to spread in the neighorhood: nor maintain a water reserroir wick percolates thraugh the neighooring land; nor neglect to kecrs its winarves, dikes, and ziers in repair.(6

(1) Terry v Hayor, 71 N.Y. 580.

(2) Robert $\vee$ SadIer, IO4 W.Y. 229.

(3) Detroit v Corey, 9 rich. I65.

(4) Worden $r$ Hew Dedford, IJI Nass.-

(5) Nayor $v$ CuIIen, $58 \mathrm{Ga}$. 346. Rowland $v$ Kalanazoo, 49 Hich.553

(6) Rading $v$ Briggs, 37 N.Y. 256. Baily v H.Y.J Hill 531. Hercy Dock Co. II I. of L. 7I5:Hortherin Co. v Chicago, 99 U.S. 635. 
GHAPRER VI.

STEWERS .

Sec. 1. Liability. A rumicipal corporation is regarded as the owner of its sewers. It is Iiable to the persons connected with the main sewer for any neglect to keep the sewer in repair; or by so negligently constructing it as to become a trespasser on private property.(I) Although the city is not Iiable for omitting to built a semer or drain, yet, having exercised its porer the duty is not discretionary but becomes ministerial..

They are held Iiable, (1) where the agents or servants In constructing the sewer do the work negIigently or unskillfully whereby unnecessary damages happen to adjacent walls, cellars etc,(2) where the sever is so constructed or maintained as to constitute a nuisance,(3) where the direct result of the manner in which the sewer is constructed, is the flooding of a person's premises, it is thus liable for trespass to the freenold, (4) where in digging a serer in a pubIic street, a dangerous excavation is left open and unguarded, whereby a travelier ithout fault on his part is injured.(2)

(1) Shearman \& Redfield, 287;

(2) Thompson on Hegligence, 750. 
In the latter case the liability may artse even if done by an independent contractor, when it ina notice of the dangerous defect express or implied, so that the city could by reasonable dilffonce have repaired or averted the defect.(I

sec. 2. Degree of Care. The duty devolves upon the corporation to exercise a reasonable degree of care and watchfulness in ascertaining the condition of the sewers, from time to time, and prevent them from becoming delapidated or obstructed. 2 The omission to make such an examination and to keep then clear is a negleat of duty which renders the city liable.(2) Wre no negligence, either in plan ar con-, trol is alleged, the plaintiff cannot recovem where the damages are caused by a mant of judgment, Not after extraordinary rains or the like from which the injury resulted.(z) The plans, methods and Iocation of sewers is a more difficult qustion. This is generally a legislative powera question'resting in the sound discretion of the aity council. The courts cannat revier such decisions, thus a court of equity cannot compel a city to constmat a new sewer, where the existing one is of insufficient capacity to carry off the (1) Fort v Beritt, 47 Ind. 397. Darlon v Brooklyn, 46 Barb.604. (2) HC Carty $v$ Syracuse, 46 H.Y. 194. (3) Collind v Philadelphia, 13 Pa. St. 272. Smith $v$ iayor, 4 Hun 637 . Barry $v$ Lowell, 8 Allen 127. 
sewage, (I) nor enjoin the construction of a sewer because of the inadequacy of the size.(2)

If $a$ public serrer becomes incapable of discharging the volume of water for which wt was designed, either by a change of surface drainage in consequence of the drainage of streets or by the natural gronth of the city, the corporation will not be liable for damages by reason of not enlarging it.(5) Bur there are many leading ceses, deciding that the skill and care, which is incrmbent upon the ctty relates as well to the capacity of the sewer when built as to the mere mechanisin in its construction; as well to its plans as to its execution.(4) d. Cool in Detroit $v$ Beckman, limits such liability in defective plans to a direct invasion of private property. A municipal charter never could give authortty to appropriate the freehold of a citizen without compensation, whether it be aone by : an actual taking of it for streets or by flooding it, so as to interfere with the omer's possession. The decision rebukes the general theory as "so vicious that it cannot possibly be omitted".(5) Another exception to the general mie is where the city is guilty of gross intrinsic negligence in the plans and specifications.(6)

(I) Horton $\vee$ Mayor;4 Lea. 38 (2) Thompson, 752.

(7) Indianopilis $v$ Huffer, 30 Ind.235: (4)Mun $v$ Ittsburg, 40 Pa. St. 364.(5) woad on Wuisances, 752; Seifert b Brookiyn, 101 N.Y. 342. 


\section{CHAPTER VII.}

SURFACE WATERS .

$--\infty 00--$

sec. 1. Hatural Streams. Cities having the porer to grade and repair their highways, must in such imp rovements for the public discomode the property of the adjacent omners. Such injuries tnsually from surface water, diverted by the Erade onto the lower proprietors Iand is damnum absque injuria. It is well settled that a city cannat construct an insufficient bridge, culvert or any other obstruction to interfere with a natural stream. It must have the unobstructed and uncontaminated flow for the enjoyment of the contiguous property owners.(I)

sec. 2. Surface Dratnage. A city like an individual ist not liable for consequential damages resulting from surface water in grading and improving public streets, although increased quentities is thereon.(2) The aity must provide for and dispase of, the surface water which falls upon its streets, and in the discharse of that duty neither the city or its agents can be proceded against for aamages sustained by an individual. We noted before that there is

(1) Gardner v Newburg, 2 Johnsons Ch. 162;

(2) Goodale v Tutile, 29 N.Y. 459. Weis v Kadison, 75 Ind.24I. Rađclifre v BrookIyn, 4 N.Y. 195. 
no liability on tive part of the city for omission to construat drains, sewers or make improvements. This is discretionary and when undertaken good faith and diligence are required.(1) Although the injured property owner has no remedy, generally, he can recover for negligence in the plans themselves in making imptovenent. In determining the size of culverts or the grade of highways, reasonable skill must be exercised or an action Iies for darages to an injured individual, but Hew York seems to deny such liability.(2) so where the drainage is collected in a common channel and thrown upon or carried over the land of a private owner, the injured owner has a remedy. In graiing a street, a city is liable if it turns a stream of vater upon the grounds and into the cellar of one of its eitizens. It can relieve itself by improvements, but, not by positively throwing the drainage upon private land.(3) Stuch consequential damages are not taking property:for public use unIess the constitution, as many constitutions do, include such taking in their eminent domatn.(4) The New York constitutional provision is not braad enough to include such compensation.

(I) Siefert v BrookIyn, IOI W.Y. $36 I$.

(2) Van PeIt $v$ Davenport, 42 Iowa 308; BiIIan, I04I.

(3) Rice v EvansviIle, I08 Ind. 12.

(4) Bilion; 990; Foot v Bmuson, 4 Lansing 47. 
CIIAPTIR VIII.

HIGLYAYS AND SIDUWALIS.

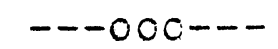

Sec. I. RuIes of Iiabliity. Municipalities have general control of their streets whether tive fee be in them, as orners or trustees or in the property owners. They must make the necessary repairs and improvements, by grading, draining, building sidowalis and crossmalks as the circumstances and growtin of the city may require. The general mule is that the cities are Iiable for damages caused to travellars from defective and mase streets under their control. In repairing or constructing highrays the corporation is reguired to use ordinary care and foresigit, for a lack of winich it is Iiable in damages to tro rarty injured.(1) It is always the duty of the city to keep tine streets free from abstructions and nuisances: sufficientiy level and guarded by rails; or Iights when necessary to enable safe and convenient travel. (2) Such protection extends upwards to annings, signs and walks, as well as the ground and sideralk.(3) Highrays and sidewalks in a populous city rust be iect clear and unobstructed in its full width; while in a town this may not be necessary. (1) Hime v H.Y. 47 N.Y. 330 . Dilion on jumicipal Corpor. p.ag9 (2) Buffalo v Holloway, 7 I.Y. 403.

(3) Hubbel v Yonkexs, $104 \mathrm{~N} . \mathrm{Y} .434$. 
to such an extent.

This liability arises from the comnon law or plied by the acceptance of the charter. But the English, Canadian and courts

Hew England do not apply strch frizlied liability.(I) some states as Wisconsin and richigan, have statites exempting their cities from their comion law liability, no suit can be brought against such cittes unless the liability is created by statute.(2) Those courts reason, that the city in controlling its streets does so in a governmental or public capacity, as a branch of the state, and shourd be exempt from civil litigation and only subject to penal punishment. This argument is apprdved by Judge Dilion, but the iron-clad precedents hinders such inclinations of the courts in other jurisdictions.

sec. 2. Slderalis. Sidewalis and street crossings are comprehended in the terms streets and highways.(3) The duty in respect to carriage ways, cross walks, sidemalks and bridges is to maintain them with reasonable safety for the travelling public.(4) Ice and snow must be cleared with due diligence; "nuisances and obstructions must be removed, whether

(1) King v Broughton, 5 Bur. 210.

(2) Dilion on. hun. Cor., 1000 .

(3) WiIson v Watertom, 3 Itin 500.

(4) Hines $v$ Lockport, 60 Earb. 378. 
on the ground or ovorhead: railings must be attached when necessary and all other precaution which pmadence requires to protect the travelling public.(1) A violation of a city ordinance is not negligence por se between the parties.

sec. 3. Ice and snow. The mere sitpperiness of a sidewalk occasioned by ice or snow, not accumulated so as to constitute an abstruction is not ordinarily such a cerect as w1I make tine city liable for danages to one injured thereby. But where the snow and ice exists upon a street in such shape as to form an abstruation, being heaped up or having a rough surface the city is Iiable.(2) This distinction is held by many courts, but the Ner York courts have never made such a fallacious distinction. It matters not whether the ice is in ridges or smooth, the question is, does it form an abstruction. The municipal authorities are called upon: to observe and see that the fublic strects are reasonably oleared of snow and ice in winter. In such cases the Iav only requires what is feasible and reasonable.

If from ant artificial cause an existing nuisance, as ... spouting hydrants, adjacent leaders etc., the ice is primarily caused or the danger increased the city is almays (1) Moore $v$ Gadsen, 87, in.Y. 04. (2) Kinney v Troy, IO8 N.Y.567. 
Ifable.(I) But the question of nogligence in protecting streets is one for the jury. They must consider all the facts and circumstances and determine whether the city was neglifent. The contributory negligence is always a good degense on the part of the city. In order to recover from the city the plaintiff must be free from any element in caust Ing the injury complained of.

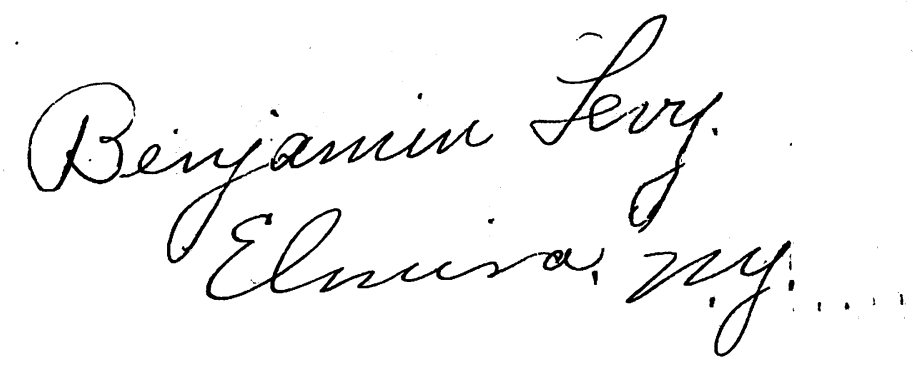

(1) Todd v Troy, GI N.Y. 500. Landolt $v$ Morwich, 37 Conn. 615. 


\section{BIBLIOGRAPII. $---000---$}

Dilion's Inunicipal Corporation, 4th Ed. 1890. Beach's Puiblic Corporation, 1393. Murphy"s intuicinal corporation, 1891 (Pa.)

Peck's Municipal Corporation, 1892 (Onio) Richard's inducipaI comporation, I390 ( $\mathrm{Pa}$. Tiedeman"s inunicipal corporation, 1893. Morril's City Hegligence. Ray's Imposed Duties, IS94. Shearmen and RedfieId on NegIiEence, Chapters 12-I7. Thompson on Hegligence, VoI. 2. Wood's Law of Juisances, and idx. American and English Corporation Cases. American and English Enay. of Law, Vols. 15, 24, 16. Thompson's Comentaries on Corporation Lam, 1895. 